\title{
う蝕予防剤としての錯化合物に関する研究
}

\author{
第 II 報 \\ う蝕源性食餌 (6-PMV) で飼育されたラット実験う蝕に \\ 対するジピリジル系化合物のう蝕抑制について \\ 加茂常 一*

\section{STUDIES ON THE CHELATING COMPOUNDS AS AN ANTI-DENTALCARIES AGENT} \\ Effects of inhibition of dipyridyl compounds on experimental rat caries \\ produced with high sugar diet, 6-PMV.
}

BY

Tsunekazu KAMO

To have better anti-dentalcaries agents, it is desirable to find out the medicines having properties to localize on the surface of tooth, as well as to inhibit growth of oral bacteria, and then to protect caries lesion.

Studies along this line have revealed that among several dipyridyl compounds examined, $o$-phenanthroline has these characters in an appreciable degree, and neo-cuproine has also an antibacterial nature and protects experimental rat caries cavities but is lacking in an ability to localize on the surface of tooth.

1) Wister rat's molars challenged with high sugar diet, 6-PMV which is called caries-producing diet, for 90 days. 80 wister rats were used in the present experiment. Among the two rats feeded in one cage, one was treated with $o$-phenanthroline or neo-cuproine and the other was control. By comparing the number of caries found in the rats treated with these two compounds to that of control, using $x^{2}$-test method, it was shown that $o$-phenanthroline inhibited caries producing in the order of $\mathrm{P}<0.05$, and neo-cuproine in the order of $\mathrm{P}<0.30$.

2) Knoop hardness of enamel surfaces were measured before and after the treatments with these compounds. Differences of hardness hetween these two experiments has not been detected.

3) $\mathrm{Ca}^{+}$or $\mathrm{Fe}^{*}$ complexes of $o$-phenanthroline were synthesized, and an antibacterial nature of these two complexes were tested by Disk method using St. mitis 39 .

* 東京医科菌科大学・医用器材研究所化学部門

Division of Chemistry, Institute of Medical and Dental Engineering, Tokyo Medical and Dentul University 昭和 42 年 10 月 20 日受付 
飲料水中に弗素の含有量が高い地方では，弗素 が硬組織形成を障害して多量に斑状歯が形成さ れ，この斑状歯にはう蝕が生じ難いことが知られ ており，このことから，飲料水への弗素イオンの 添加または歯牙の 弗素処理がう蝕抑制を示すこと が期待され実際に行なわれている。弗素イオンの ら蝕抑制についての作用機序は種々の見地から検 討されているが，弗素イオンの歯質への侵入によ り歯質自体の耐酸性を増加することにより，う蝕 抑制が達成されるものとされている。このことは 歯質中の弗素イオン 含有量を高めることによつて う蝕抑制が達成できるとも考えられる。

他方では，口腔内微生物がう蝕に直接あるいは 間接的に関与しているということが多くの研究者 によつて認められている1-8)。すなわち，う蝕予 防としては，1）歯質自体の構造的耐う蝕性を増 強すること，2）う強に関与する口腔内微生物を 殺菌あるいは発育抑制すること，の 2 つの面から 研究が行なわれている。例えば弗素イオンが細菌 代謝中に弗素燐酸マグネシウムを形成して $\mathrm{Mg}^{+}$を 除去し，エノラーゼの生成を著しく阻害すること

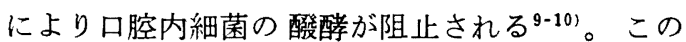
ような機序によつて弗素イオンのう蝕予防作用を 解明する説も行なわれている。したがつてら蝕の 誘因菌の殺菌もしくは抑制にう蝕予防の原理を置 くことは妥当であろう。

う蝕予防を目的とする手段として，弗素のみで はなく，抗菌性物質の使用も考えられ，抗生物質 が採り上げられてきた。Shaw ら ${ }^{31}$ はグラム陽性 菌に対して効力のあるペニシリンを使用し， ラッ トの実験う蝕を抑制した。また, Orand ら, Keyes らは抗生物質を径口的に与える方法により，そし て Shieredはタイロスライシン入りの歯みがきを 2 年以上人間に使用することによりら蝕が抑制さ れたと報告している。

これらの結果から，一般にグラム陽性菌の発育 抑制に働く抗生物質はう蝕抑制に効果を示すとい われている。しかしながら，実験的にう蝕予防を 示す抗生物質を実際に使用する場合には投与方法 によつてそれぞれ 種々の難点があると考える。例 えば飲料水または食物と一緒に混和して投与する
方法は, 抗生物質が歯面に長時間停滞せず唾液中 に流出し，消化管に移行する結果，薬物の好まし くない副作用が現われる。すなわち，腸内に移行 した薬物が腸内細菌を減少させ，下峲による体重 の減少や死亡という現象が生じた。また，抗生物 質を添加した歯みがきを口腔清掃時に使用するこ とによつてう蝕予防を達成する方法は，薬物と歯 みがき成分とが錯塩等を形成して 殺菌作用が減退 するおそれがある。また，mouthpiece を用いて歯 牙表面に薬物を局所的に塗布する方法は，5蝕予 防方法としては実際上実施困難であろう。

また，抗生物質の使用においては，周知のよう に菌交代現象のような予期しない口腔内疾病が起 るのでその使用には限界がある。

著者は，歯牙表面に対し強い吸着性を持ち，か つ口腔内細菌（特に，鼠のう蝕誘因菌とされてい るグラム陽性菌）に対して殺菌作用を示す化合物 を見出せば，このような化合物は歯表面に付着す る細菌もしくは細菌叢に基因するう蝕の成因や促 進作用を防止しえるのではないかとの考えから， 本研究に着手した。

前報 ${ }^{1)}$ において報告した吸着試験により多数の 合成化合物について 歯質への吸着性が高いものを 選び出し，これらについて $2 ， 3$ の酸生成性の口 腔内細菌に対する抗菌性試験を行なつた結果， シ ピリジル系化合物が満足すべき 程度に歯質への吸 着性と抗菌作用を示すことがわかつた。

さらに，数種のジピリジル 系化合物について Dentin に対する吸着性および $2 ， 3$ の口腔内細 菌に対する抗菌性について精査した。

抗菌性試験では，o-phenanthroline および neocuproine は St. mitis 39, St. faecalis 7159, な らびに Lacto. casei 7469 の発育抑制を示し， ophenanthroline のこれら 3 菌株に対する制菌力は 1:32000, neo-cuproine の St. mitis 39, Lacto. casei 7469 に対する制菌力はそれぞれ $1: 64000$, St. faecalis 7159 に対するそれは $1: 32000$ であつ た。

一方, Dentin への吸着試験では, $o$-phenanthroline は $21.0 \%$ の高い吸着值を示し, neo-cuproine はほとんど吸着を示さなかつた (Table 1)。 
Table 1 Adsorption on dentin and antibacterial activities of these two compounds

\begin{tabular}{l|c|c}
\hline \multicolumn{1}{c|}{ compounds } & $o$-phenanthroline & neo-cuproine \\
\hline adsorption on dentin & $+(21.0 \%)$ & \pm \\
antibacterial activity & + & $\#$ \\
St. mitis 39 & $1: 32000$ & $1: 64000$ \\
St. faecalis 7159 & $1: 32000$ & $1: 32000$ \\
Lacto. casei 7469 & $1: 32000$ & $1: 64000$
\end{tabular}

大西正男，尾崎文子ら ${ }^{12-14)}$ は，一連のラット実 験う蝕研究の中で, 低カゼイン食の 6.PMV で飼 育すると，高カゼイン食で飼育する場合よりも高 いう蝕発生率が見られると報告し，低カゼイン食 (6-PMV) をう蝕源性食餌と名付けた。この6PMV を生後 4 週目より 90 日間 ラットに与える と, ラット臼歯に多くのう蝕が発生する。

著者は，断続的に $o$-phenanthroline および neocuproine をラットの歯牙に塗布し，6-PMV を用 いて飼育したところ，o-phenanthroline にう蝕抑 制効果がみられたのでここに報告する。

\section{実験 1 う蝕抑制について}

著者は前報で，数種のジピリジル系化合物 の Dentin に対する吸着性および $2 ， 3$ の口腔内細菌 に対する発育抑制効果を観察した。そして緒言で のべたように 2 種類の薬物，すなわち抗菌性およ び吸着性を合せ有する $o$-phenanthroline,および抗 菌性を有するが吸着性のほとんどないneo-cuproine を用いてう蝕抑制実験を行なつた。

\section{実験材料および実験方法}

う強抑制実験に使用したラットの総数は80匹で あり，1籠に 2 匹ずつ餌育し， 1 匹には薬物の溶 液を塗布し，他方の 1 匹には滅菌蒸溜水を塗布し た。20籠（40匹）を 1 群として 80 匹を 2 群に分 け, 一方の群には $o$-phenanthroline 塗布し, 他 群の薬物塗布用ラットには neo-cuproine をエーテ ル吸入麻酔下で 1 週間に 1 回薬物または滅菌蒸溜 水を浸たした綿球を用いて塗布した。これらの薬 物の濃度は $1 \mathrm{mg} / \mathrm{ml}$ のものを使用した。

実験開始時の体重 40 50g の市販の純系 wister 系ラットを低カゼイン食 (6-PMV) で室温 $23^{\circ} \mathrm{C}$, 湿度 $50 \%, 90$ 日間飼育した後，クロロフォルム

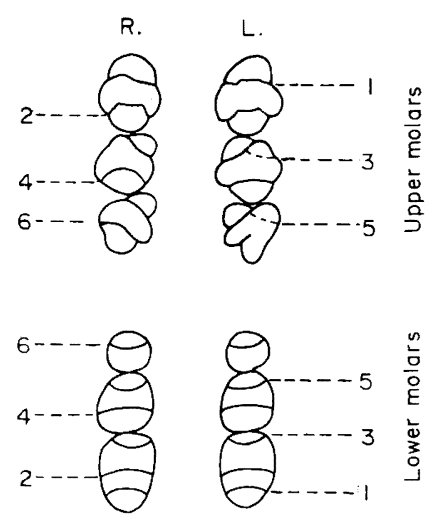

Fig. 124 Locations where the carious lesion has been found.

䏫酔下で屠殺し，頭部を離断し，10\% 中性フォル マリン固定したものについてう窩を数えた。実験 中動物の体重は毎週 2 回ずつ測定した。

ら窩は上下顎の歯について測定し, Fig 1 に示す 24 裂溝にみられるものを JIS 規格 12 号メリケン 針で探索し，見つかる限りのものを記載した。裂 溝のう蝕性破壊が大きくなり，咬頭を越えて隣接 の裂溝底以上に拡大しているように見える場合に は，厳密には独立 2 個か拡大 1 個か区別できない ので，2 個のう窩と見做した。裂溝中には端の方 で2つに分岐しているものもあるが，う窩が主裂 溝にあつても副裂溝にあっても，1個のう窩とし て数えた。そしてまず, 薬物塗布群と対照群との 間にう窩の出現する部位的傾向の有無を調べた。 また, 薬物のう蝕抑制効果の判定は薬物塗布群と 対照群とのう蝕罹患性を比較することによつて行 なつた。

\section{実験結果}

実験方法中に記した方法により検出しうるかぎ りのう蝕を数え，総匹数中に現われたう蝕を部位

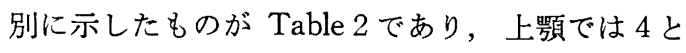
6 の位置, すなわち第 2 大臼歯の遠心溝と第 3 大 臼歯の遠心溝，下䫛では，4 2 の位置，すなわ ち第 2 大臼歯の近心溝と第 1 大臼歯の中心溝にう 蝕出現傾向があつた。また, 左右のう蝕出現傾向 の差はほとんどなかつた。部位的う蝕出現傾向お よび左右のう蝕出現傾向は薬物塗布群および対照 群ともに見られた。 
Table 2 Number of cavities in rats at various locations

\begin{tabular}{|c|c|c|c|c|c|c|c|c|c|c|c|c|}
\hline \multirow{3}{*}{\multicolumn{2}{|c|}{ 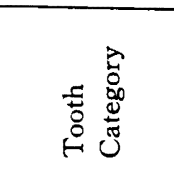 }} & \multirow{3}{*}{ : } & \multirow{2}{*}{\multicolumn{2}{|c|}{$\frac{\text { o-phenanthroline }}{20 \mathrm{rats}}$}} & \multirow{2}{*}{\multicolumn{2}{|c|}{$\frac{\text { neo-cuproine }}{18 \mathrm{rats}}$}} & \multirow{2}{*}{\multicolumn{2}{|c|}{$\frac{\text { control [A] }}{20 \mathrm{rats}}$}} & \multirow{2}{*}{\multicolumn{2}{|c|}{$\frac{\text { control [B] }}{20 \mathrm{rats}}$}} & \multirow{2}{*}{\multicolumn{2}{|c|}{$\begin{array}{c}\begin{array}{c}\text { Control } \\
{[\mathrm{A}]+[\mathrm{B}] \times 1 / 2}\end{array} \\
20 \mathrm{rats}\end{array}$}} \\
\hline & & & & & & & & & & & & \\
\hline & & & $\mathrm{R}$ & $\mathrm{L}$ & $\mathrm{R}$ & I & $\mathrm{R}$ & $\mathrm{L}$ & $\mathrm{R}$ & $\mathrm{L}$ & $\mathrm{R}$ & $\mathrm{L}$ \\
\hline \multirow{6}{*}{ 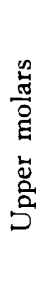 } & \multirow{2}{*}{$1 \mathrm{st}$} & 1 & 4 & 2 & 4 & 0 & 8 & 5 & 2 & 5 & 5 & 5 \\
\hline & & 2 & 4 & 3 & 2 & 4 & 7 & 10 & 7 & 9 & 7 & 9.5 \\
\hline & \multirow{2}{*}{ 2nd } & 3 & 1 & 1 & 1 & 0 & 1 & 4 & 1 & 3 & 1 & 3.5 \\
\hline & & 4 & 4 & 4 & 7 & 6 & 7 & 10 & 9 & 9 & 8 & 9.5 \\
\hline & \multirow{2}{*}{ 3rd } & 5 & 0 & 0 & 0 & 0 & 3 & 0 & 1 & 2 & 2 & 1 \\
\hline & & 6 & 3 & 2 & 5 & 3 & 9 & 8 & 7 & 9 & 8 & 8.5 \\
\hline \multirow{6}{*}{ 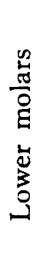 } & $3 \mathrm{rd}$ & 6 & 2 & 1 & 1 & 2 & 6 & 5 & 4 & 5 & 5 & 5 \\
\hline & \multirow{2}{*}{ 2nd } & 5 & 2 & 0 & 2 & 3 & 6 & 9 & 8 & 9 & 7 & 9 \\
\hline & & 4 & 12 & 13 & 14 & 13 & 18 & 16 & 18 & 17 & 18 & 16.5 \\
\hline & \multirow{3}{*}{ 1st } & 3 & 0 & 2 & 0 & 1 & 0 & 5 & 2 & 3 & 1 & 4 \\
\hline & & 2 & 7 & 9 & 13 & 8 & 13 & 14 & 18 & 19 & 15.5 & 16.5 \\
\hline & & 1 & 1 & 0 & 4 & 2 & 7 & 4 & 1 & 5 & 4 & 4.5 \\
\hline
\end{tabular}

ラット 1 匹についてう蝕䍜患した部位が何個あ るか, すなわち, う窩数と匹数との関係をしらべ, 薬物塗布群と対照群とを比較することにより，う 蝕抑制効果を判定した。Table 3 はう窩数と匹数 との関係を示すもので, 薬物塗布群と対照群と比 較すると，薬物塗布群ではう蝕罡患しにくいラッ トが多くみられた。

Table 3 Number of locations of carious cavities

\begin{tabular}{r|c|c|c}
\hline \multirow{2}{*}{$\begin{array}{c}\text { Ranking } \\
\text { of } \\
\text { cavities }\end{array}$} & \multicolumn{3}{|c}{ Number of carious rats } \\
\cline { 2 - 4 } & $o$-phenanthroline & neo-cuproine & control \\
\hline $0 \sim 2$ & 6 & 3 & 1.5 \\
$3 \sim 5$ & 10 & 8 & 3 \\
$6 \sim 8$ & 3 & 5 & 6 \\
$9 \sim 11$ & 1 & 2 & 4.5 \\
$12 \sim 14$ & 0 & 0 & 3 \\
$15 \sim 17$ & 0 & 0 & 2 \\
\hline Total & 20 & 18 & 20
\end{tabular}

$o$-phenanthroline 群や neo-cuproine 群のう窩数 と匹数との関倸は明らかに正規分布をしていない と思われたので，薬物塗布群と対照群との間にう 蝕感受性の差がないと仮定して， $\chi^{2}$-test を行なつ た結果， o-phenanthroline 塗布群は $\mathrm{P}<0.05$ で有
意と見做され，また， neo-cuproine 塗布群も $\mathrm{P}<$ 0.30 で有意と見做された。

そしてまた，o-phenanthroline 群と neo-cuproine 群との間の差を検定したところ，o-phenan. throline 群は $\mathrm{P}<0.30$ で有意を示した。

Fig. 2-A は対照群ラットのう蝕の状態を示し, 歯冠部崩壊およびう蝕の多発を示している。

Fig. 2-B は $o$-phenanthroline 塗布 ラットでう 蝕䍜患のないことを示している。

Fig. 2-C は neo-cuproine 塗布ラットでら蝕䍜 患の少ないことを示している。

\section{実験 2 毒表面のかたさ}

山岸 ${ }^{15}$ は, 口腔内細菌に抗菌性を示す oxine 誘 導体の 7-n-propyl-8-hydroxyquinoline を使用し, 薬 物と Dentin との間の 錯塩生成についての実験を 行ない, 薬物が Dentin に吸着されたときDentin 自体はかたさを増加し，その錯塩は口腔内細菌に 対する抗菌性を失うことを報告した。

著者は前回に報告したように，o-phenanthroline は oxine と同様 Dentin に吸着され, また, 口腔 内細菌に抗菌性を示すということ, および o-phenanthroline 骨格を持つ neo-cuproine は吸着性を 
示さないが抗菌性を持つという結果を得ている。

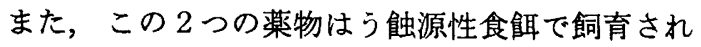
たラットのう蝕発生を抑制し，前者は $\mathrm{P}<0.05$ で, 後者は $\mathrm{P}<0.30$ で有意という結果を実験 1 で 得ている。

したがつて, o-phenanthroline が neo-cuproine よりもう蝕抑制に作用したことは，歯表面のかた さの増加に起因するとも考えられるので，knoop 硬度の測定実験を行なつた。

\section{実験材料および実験方法}

二瓶 ${ }^{16)}$ のビッカース硬度計を用いた人歯牙硬度に 、関する報告によれば，被験歯のエナメル質に加え る荷重は $50 \mathrm{~g}$ が至適であるとしている。しかし， ビッカースかたさは歯の表面のような 繊維性構造 を持つ試料には適さない。そこで，著者はこのよ うな方向性の顕著な構造物の測定に適する knoop かたさを用いた ${ }^{17 ! 。}$

試料に加える荷重が大きければ大きいほどダイ ヤモンドの圧痕は大きくなつて 測定しやすいが， しかし表面の 変化を問題にする場合にはできるだ け荷重の小さい方が良いとの考えから，荷重 $50 \mathrm{~g}$ とし, 荷重速度は 15 秒, 荷重保持時間は 15 秒で 実験を行なつた。

試料に歯牙を用いる場合，そのかたさは乾燥状 態により変化するので，モデリングコンパウンド 固定後，室温 $23^{\circ} \mathrm{C}$ ，湿度 $50 \%$ で 48 時間放置した 後, Leitz 社製の微少硬度計 “Durimet”を使用 しknoop かたさを測定した。

試料には牛の前歯のエナメル 質表面とラットの 下瀕大臼歯のエナメル質を使用し，塗布薬物には o-phenanthroline, neo-cuproine および oxineを用 い，これらの薬物の濃度はそれぞれ $1 \mu \mathrm{mol} / \mathrm{ml}$ とした。これらの歯牙を薬物塗布前に歯軸と直角 の方向に 10 回測定し，楽物溶液を浸した 綿球で 60 分間表面に塗布し, 水洗し, 乾燥綿球により水 分を充分取り除いた 後に隣接した 部位を 10 回测 定した。

knoop かたさの式より算出された硬度表を使用 し，薬物塗布前と塗布後の試料表面のかたさを算 出し, その平均値を比較した。

$$
\begin{aligned}
& \mathrm{Hk}=\frac{14.23 \cdot 10^{3} \mathrm{P}}{\mathrm{I}^{2}} \\
& \mathrm{Hk} \cdot \cdots \mathrm{knoop} \text { かたさ } \\
& \mathrm{P} \cdots \text { 荷重 } \\
& \mathrm{I} \cdots \cdots \text { 圧子の長い方の対角線の長さ }
\end{aligned}
$$

\section{実験結果}

7-n-propyl-oxine を Dentin に塗布したとき， そのかたさの変化を測定した山岸の実験によれば 60 分間薬物を塗布された Dentin はかたさの増加 を示すと報告している。そこで,著者はまゔ oxine を使用し，前述の材料および方法で実験を行ない エナメル質表面のかたさを測定したところ，その かたさの変化は認められなかつた。そしてまた， $o$-phenanthroline や neo-cuproineについても同様 な実験を行ない，oxine と同様な成績を得た。

これらのかたさの変化を測定する実験の結果は Table 4 に示す通りであり, 薬物塗布前と塗布後 では knoopかたさの変化はほとんど認められなか つた。

Table 4 Knoop hardness of bovineinc:sor enamel.

\begin{tabular}{l|c|c}
\hline \multicolumn{1}{c}{ compounds } & $\begin{array}{c}\text { before treatment } \\
(\mathrm{Hk})\end{array}$ & $\begin{array}{c}\text { after treatment } \\
(\mathrm{Hk})\end{array}$ \\
\hline oxine & $435.36 \pm 24.36$ & $435.34 \pm 18.26$ \\
o-phenanthroline & $450.58 \pm 22.02$ & $445.84 \pm 26.84$ \\
neo-cuproine & $437.04 \pm 18.04$ & $440.58 \pm 22.22$
\end{tabular}

Knoop hardness of rat's molar enamel.

\begin{tabular}{l|c|c}
\hline \multicolumn{1}{c|}{ compounds } & $\begin{array}{c}\text { before treatment } \\
(\mathrm{Hk})\end{array}$ & $\begin{array}{c}\text { after treatment } \\
(\mathrm{Hk})\end{array}$ \\
\hline oxine & $306.84 \pm 17.64$ & $306.91 \pm 17.71$ \\
o-phenanthroline & $305.01 \pm 20.61$ & $303.53 \pm 19.13$ \\
neo-cuproine & $303.06 \pm 18.66$ & $305.89 \pm 11.89$
\end{tabular}

\section{実験 3 金属塩の抗菌性}

歯牙表面や歯垢に吸着された $o$-phenanthroline または neo-cuproine はそのままの形で歯牙表面上 に存在するのかまたは歯牙成分のカルシウムと錯 塩を形成しているのかを化学的に決定することは 吸着された薬物が余りに微量のため極めて困難で ある。

o-phenanthroline または neo-cuproine がいずれ の形でう蝕抑制に作用するのか検討するため, 
$o$-phenanthroline の $\mathrm{Ca}^{H}$-complex および $\mathrm{Fe}^{H}$. complex を合成してその抗菌性を調べた。

\section{実験材料および方法ならびに結果}

標準菌株 St. mitis 39 を $1 \%$ glucose 加 brain heart infusion broth 寒天培地に混釈し, o-phenanthroline $の \mathrm{Ca}^{\mathrm{H}}$-complex $\mathrm{Fe}^{\mathrm{H}}$-complex $の 1$ $\mathrm{mg} / \mathrm{ml}$ 溶液を使用し, 抗菌性を Disk 法によつて 測定した。

なお， Ca ${ }^{H-}$-complex は $o$-phenanthroline および 酢酸カルシウムそれぞれ $10 \mu \mathrm{mol}$ の $99.5 \%$ エチ アルコール溶液を作成し，それらの溶液を混合し 溶剂を蒸発乾固して得たものを使用し，また $\mathrm{Fe}^{\#}$. complex は $\mathrm{FeSO}_{4}$ を用い前述の Ca-complex の 合成と同様な方法によって得たものを使用した。

$o$-phenanthroline の $\mathrm{Ca}^{+}$-complex $\mathrm{Fe}^{\mathrm{H}}$-complex の St. mitis 39 に対する発育阻止性を Disk 法によって調べたところ, 双方ともに発育阻止を 示さなかつた。

\section{考察}

この研究において，2種類の薬物一一細菌発育 を抑制する性質と同時に Dentin に吸着される性 質を持つ $o$-phenanthroline および細菌抑制作用は o-phenanthroline よりも強いがしかし Dentin に 対する吸着性はほとんど示さない neo-cuproine一 をう蝕源性餌料 6-PMV で飼育したラットの歯面 に塗布し、ラットのう蝕抑制を観察する実験を行 なつた。

う蝕抑制の有無はう蝕数と匹数とをしらべ，薬 物塗布群と対照群との差を $\chi^{2}$-test により検定し た。その結果, $o$-phenanthroline 塗布群は $\mathrm{P}<$ 0.05 で有意であり, neo-cuproine 塗布群は $\mathrm{P}<$ 0.30 で有意であつた。また, $o$-phenanthroline 群 と neo-cuproine 群との差を検定したところ，ophenanthroline 群は $\mathrm{P}<0.30$ で有意を示した。

$o$-phenanthroline および neo-cuproine はともに グラム陽性菌の発育を抑制したが，う蝕抑制実験 の結果は, o-phenanthroline はう蝕発生を強く抑 制し， neo-cuproine はあまり強く抑制しなかつ た。

その理由としては, $o$-phenanthroline が歯面に
吸着されるために口腔内により長時間停滞するた めと考えられ，また neo-cuproine は o-phenanthroline よりも抗菌性は強いが吸着性が低いので 歯面および口腔内に停滞する時間が短かいために う蝕抑制効果が低かつたと考える。しかし薬物塗 布群相互間の差を検定したところ $\mathrm{P}<0.30$ であま り差はみられなかつた。

6-PMV を用いて動物飼育中対照群も薬物塗布 群のラットも同程度の体重増加を示した。また, 今回の薬物塗布の濃度では, 塗布薬物が消化管に 移行するために起る好ましくない副作用は認めら， れなかつた。

う窩の出現する傾向は，薬物塗布群も対照群も 左右対称性で，しかも同程度のう窩を出現し，ま

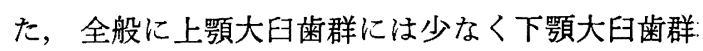
には多くのう窩を認めた。特に上顎では第 2 大曰 歯の遠心溝と第 3 大臼歯の遠心溝に, 下效では第 2 大臼歯の近心溝と第 1 大臼歯の中心溝にう蝕が. 多く出現した。

これらの溝にう蝕が好発するのは食物残査が停 滞しやすい構造や自浄作用が充分に行なわれない ためと思われる。このようなう蝕の出現傾向は薬 物塗布群も対照群も示したがしかし，両群の間の う蝕によつて破壊される歯質破壊の程度の差は多 少異るように思われた。例えば，対照群にはう蝕 による破壊が著しいものが多く，すなわち，5蝕 性破壊が歯髄にまでおよんでいるものや，さらに 破壊が進行して残根状態になつてしまつたような う歯が多く観察された。しかし薬物塗布群では歯 冠の破壊の著しい歯牙はほとんど認められなかつ た。したがつて，グラム陽性菌に対し抗菌性を示 し，それと同時に Dentin と強く吸着する性質を 持つ $o$-phenanthroline はう蝕抑制を示すことがわ かつた。しかし高濃度にこれらの錯化合物を実験 動物に長期間投与した場合の動物の組織および臟 器の変化についての検討はしていない。

また，7-n-proply-oxine を歯表面に塗布した時， その表面硬度が増加するということから, o-phenanthroline や neo-cuproine がう蝕抑制に働いた のは歯表面の硬度を増加したのではないかと考え knoop かたさを測定したところかたさの変化はみ 
られなかつた。したがつて 歯牙自体が抗う蝕性を 增したと考えるよりも，う蝕抑制性は抗菌性によ るものと推測するのが妥当であろう。

また，o-phenanthroline の $\mathrm{Ca}^{\mathrm{H}}$-complex および

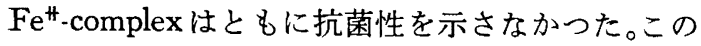
ことは，う蝕抑制実験において塗布された $o$-phenanthroline は歯牙表面上に遊離の形で吸着されて いることを示唆するものである。

正常およびう蝕のエナメル質表面は厚いフェル 卜様の膜によって覆われており，それが内部にで きた有機酸の洗い出しを妨げているという ${ }^{181}$ 。そ して，その細菌性の膜の中に酸生成菌が存在す るとき，膜自身がエナメル質をう蝕化するのに 都合のよい条件を提供していると考えられてい $3^{19.20)}$ 。また，その膜内に存在する菌種の分離や それらの細菌自身および細菌膜のう蝕との関倸の 有無についての研究が進められている21.22!。した がつて, o-phenanthroline や neo-cuproine は, こ の歯牙表面を覆う細菌性膜の形成やその膜内にあ る酸生成菌の発育を抑制したため, ラットう蝕の 発生を低下させたと考えることもできる。

\section{総 括}

う蝕抑制剤としてより優れた薬物を発見するた めには，薬物が歯面に吸着されてそこに局在する と同時に，その薬物がう蝕誘因菌の発育抑制を示 すことが望ましい。このような観点にもとずき， 著者は，前報において，多数の合成化合物の中か ら歯質への吸着性が高いものを選び出し，これら について $2 ， 3$ の口腔内細菌の発育阻止性を検討 した結果, $o$-phenanthroline は吸着性と同時に抗 菌性を示し, neo-cuproine は Dentin にはほとんど 吸着しないが細菌の発育抑制作用は $o$-phenanth. roline より強いことがわかった(Table 1)。

著者は今回これらの薬物のう蝕抑制効果につい て動物実験を行ない，実際にう蝕を抑制するかど うかを検索した。

1）万蝕源性飼料 (6-PMV) で, wister 系ラッ 卜を90日間飼育し，う蝕を発生させ，対照群と 薬物塗布群とのう蝕発生状態を比較し, その差を $\chi^{2}$-test により検定した。その結果，o-phenanthro- line 塗布群では $\mathrm{P}<0.05$ で有意であり， neocuproine 塗布群では $\mathrm{P}<0.30$ で有意であつた。 また, 一方, $o$-phenanthroline 群と neo-cuproine 群との間の差を検定したところ，o-phenanthroline 群は $\mathrm{P}<0.30$ で有意と見做された (Table 3$) 。$

う蝕の出現傾向は薬物塗布群でも対照群でも同 じような傾向を示し，左右対称性に同程度数のう 冎が出現した。その好発部位は，上顎では第 2 大 臼歯の遠心溝と第 3 大臼歯の遠心溝で，下䫟では 第 2 大臼歯の近心溝と第 1 大臼歯の 中心溝であつ た (Table 2 )。

2) これらの薬物がう蝕抑制に作用したことは 歯表面のかたさの増加に起因するとも考えられる のでその表面の硬度を測定した。

薬物を歯表面に作用させ knoop かたさを測定し たところ, 塗布前と塗布後の knoop かたさの変化 は認められなかつた(Table 4)。

3) $o$-phenanthroline $の \mathrm{Ca}^{+{ }^{H}}$-complex $や \mathrm{Fe}^{\# \text { - }}$ complex は抗菌性を示さなかつた。したがつて歯 牙表面に塗布された $o$-phenanthroline は，少なく とも一部は遊離の形で歯牙表面に留まり，それが ら蝕抑制の効果を示したものと思われる。

稿を終るにあたり，本研究を通じて御指導と御校閲を 賜わつた石川正幸教授，三村二教授，大西正男教授，な らびに堀川高大教授に䔆んで感謝の意を表します。また 御教導下された鹰森健志郎助教授をはじめ歯学部微生物 学教室の方々, 小椋秀亮助教授をはじめ歯学部薬理学教 室の方々，尾崎文子先生をはじめ菌学部予防歯科教室の 方々,ならびに金子主税助教授をはじ医用器材研究所 化学部門の方々に深謝致しま卡。

本論文の要旨の一部は昭和 42 年口腔病学会 2 月例会に おいて発表した。

\section{参考文献}

1) Orland, F. J., Blayney, J. R., Harrison, R. W., Reyniers, J. A., Trexler. P. C., Wagner, M., Gordon, H. A. \& Luckey, T. D. : Use of the germfree animal technic in the study of experimental dental caries. [I] Basic observations on rats reaved free of all microorganisms ; J. dent. Res.. 33 ; 147-174, 1954.

2) Orland, F. J., Blayney, J. R., Harrison, R. W., Reyniers, J. A., Trexler, P. C., Ervin. 
R. F.. Gordon, H. A. \& Wagner, M. : Experimental caries in germfree rats inoculated with enterococci; J. Amer. dent. Ass., 50 ; 259-272, 1955.

3) Shaw, J. H. \& Sweeney, E. A. : Comparative studies on the influence of antibiotic substances in dental caries in the white rat and the cotton rat; J. dent. Res., 36 ; 349-360, 1957.

4) Shiere, F. R. : The effectiveness of a tyrothrycin dentifrice in the control of dental caries; J. dent. Res., 36 ; 237-244, 1957.

5) Kite, O. W., Shaw, J. H. \& Sognnaes, R. F. : The prevention of experimental tooth decay by tube-feeding ; J. Nutrition, 42 ; 89 103, 1950.

6) Jenkins, G. N.： 硧蝕に関連する食物および 垂液の化学 (Sognnaes. R. F. 編, 東京歯科大 学基礎助教授会訳 ; 鋆蝕症一その化学と予防; 医歯薬出版；東京）；131-170，1963.

7) Keyes, P. H., : Evaluation of two topical application methods used to assess the Antidental caries potential of drugs in hamsters J. Oral Thera. Pharma., 2 ; 285, 1966.

8) Zinner, D. D., Jablon, J. M., Aran, A. P., Saslaw, M. S. \& Fitzgerald, R. J. : Comparative pathogenicity of streptococci of human origin in hamster caries. Archs oral Biol.. $11 ; 1419-1420,1966$.

9) Weatherwell, J. A., and hargreaves, J. A. : The fluoride content of surface enamel from permanent and deciduous teeth. In James, P. M. C. ; Konig, K. G., and Held, H. R. (ed.). Advances in fluorine reseach and dental caries prevention, New York, Pergamon Press. : 4. 181, 1966.

10) Kay, M.I., Young, R. A., and Posner, A. S. : Crystal structure of hydroxyapatite. Nature. $204 ; 1050,1964$.

11）加茂常一：5蝕予防剤としての錯化合物に関寸 る研究, I. ジピリジル系化合物の口腔内細菌に
対する抗菌性について，東京医科料科大学医用: 器材研究所報告, I : 21, 1967.

12）大西正男，犚崎文子，三村二，小椋秀亮，王置 幸子：実験う蝕予防の研究(その1), wister 鼠 の実験ら蝕研究における EDTA-鉛注射による 硬組織内時刻描記法の応用，口衛誌，15；145， 1965.

13）大西正男，尾崎文子，玉嘖幸子：実験う蝕予防 の研究(その 2), wister 鼠に作つた糖害う蝕の 発生部位と罹患度の表現方式, 口衛誌, $15: 150$ 1965.

14）大西正男，尾崎文子，浜田みよ子：実験う蜆予 防の研究 (その 3 )，う蝕源性食餌 (6.PMV) に含 まれているカゼイン量の Pb-marked Rat にお けるら窩数に及ぼす影響, 口衛誌, $16 ; 85,1966$.

15）山岸 茂: キレート化剂 7-n-propyl 8-hydroxyquinoline の歯科臨床応用に関する 研究, 特に. 象牙質創面への応用について，日大歯学， 41 ; 168, 1967.

16）二瓶一郎：人歯牙の硬度に関する研究(第一報), 阪大歯誌，第 4 巻，1-20, 1959.

17) 簏真教 : 歯科理工学 (総論) 最新歯科学全書, 第 7 巻, 173 , 永井書店（京都）

18) Williams, J. L. ; On the structural changes in human enamel, with special reference to clinical observation on hard and soft enamel. Dent. Cos., 40 ; 505-537, 1898.

19) Williams. J. L. : A contribution to the study of the pathology of the enamel. Dent. Cos., 38 ; 169-196, 269-301, 353-374, 1897.

20) Williams, J. L. : Disputed points and unsolved problems in the normal and pathological histology of enamel. J. dent. Res., $5 ; 27-107$, 1923.

21）大西正男, 近藤亘，加藤貞治，根本元，今川興 曹：所謂ヨードコックスの生態とその培養につ いて, 日本歯科医師会学術会議会誌，36，1949.

22) Ennever, J., Robinson, H. B. G., and Kitchin, P. C.: Actinomycetes and dentobacterial plaque. J. dent. Res., $30 ; 88,1951$. 

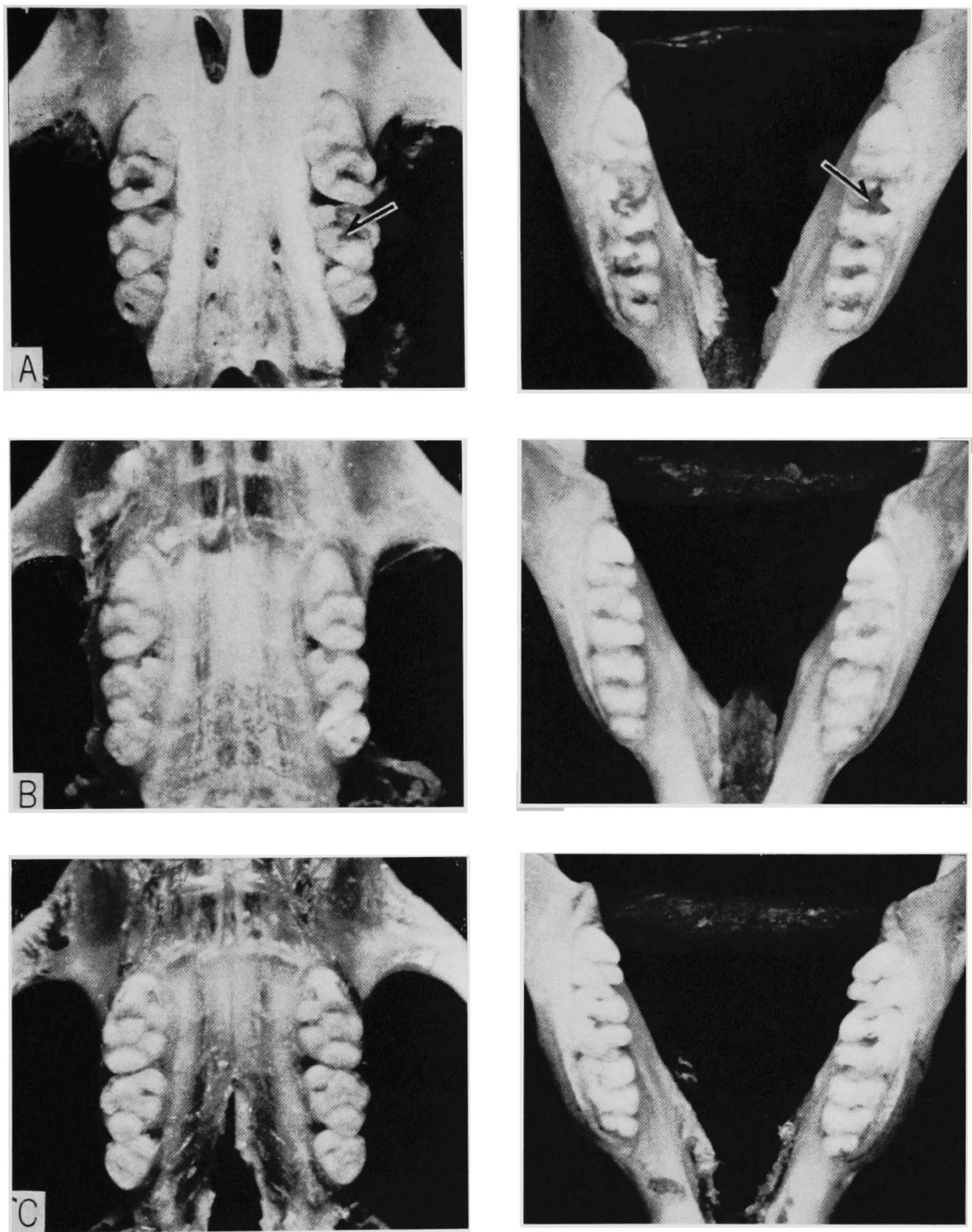

Fig. 2 Upper and lower rat's molars are challenged by a caries producing diet, 6-PMV for 90 days. A : Control rat's molars shows the most cavities.

$\mathrm{B}$ : Rat's molars treated with $o$-phenanthroline show the least cavities.

$\mathrm{C}$ : Rat's molars treated with neo-cuproine show cavities in between $\mathrm{A}$ and $\mathrm{B}$. 